\section{Risk factors for maternal death in patients with severe preeclampsia and eclampsia}

\section{Fatores de risco para morte materna em pacientes com pré-eclâmpsia grave/ eclâmpsia}

Melania Maria Ramos de Amorim 1

Luiz Carlos Santos 2

Ana Maria Feitosa Porto 3

Leila Katz Dias Martins 4

1-4 Instituto Materno Infantil de Pernambuco, IMIP. Rua dos Coelhos, 300. Recife, Pernambuco, Brasil. CEP: $50.070-550$

\section{Abstract}

Objectives: to determine the principal death causes in patients with severe preeclampsia/eclampsia and identify related risk factors.

Methods: a case-control study was performed comprising all cases of maternal death $(n=20)$ in patients with severe preeclampsia or eclampsia $(n=$ 2.541). 80 controls (survivors) were randomly select$e d$. The odds ratio and an estimate of maternal death relative risk were determined, and a multiple logistic regression analysis performed to determine the adjusted odds ratio.

Results: the basic causes for death were: acute pulmonary edema, disseminated intravascular coagulopathy, hemorrhagic shock, pulmonary embolism, acute renal failure, sepsis and three cases of undetermined causes of death. The principal risk factors were: age > 25 years old, multiparity, gestational age $<32$ weeks, lack of prenatal care, diastolic pressure $>110 \mathrm{mmHg}$, convulsions, chronic systemic arterial hypertension, HELLP syndrome, pulmonary edema, normally inserted abruptio placenta, disseminated intravascular coagulation, acute renal failure. Variables persistently related to maternal death were: HELLP syndrome, eclampsia, acute pulmonary edema, eclampsia, chronic hypertension and lack of prenatal care.

Conclusions: the principal risk factors for death in women with preeclampsia/eclampsia are the lack of prenatal care, associated to chronic hypertension, HELLP syndrome, eclampsia and acute pulmonary edema.

Key words Eclampsia, Hypertension, Death, Risk factors

\section{Resumo}

Objetivos: determinar as principais causas de óbito em pacientes com pré-eclâmpsia graveleclâmpsia e identificar os fatores de risco associados.

Métodos: realizou-se um estudo de caso-controle, com todos os casos de morte materna $(n=20)$ em pacientes com pré-eclâmpsia grave ou eclâmpsia ( $n=$ 2.541). Selecionaram-se aleatoriamente 80 controles (sobreviventes). Determinou-se o odds ratio como estimativa do risco relativo de morte materna, realizando-se análise de regressão logística múltipla para determinação do odds ratio ajustado.

Resultados: as causas básicas de óbito foram: edema agudo de pulmão, coagulopatia intravascular disseminada, choque hemorrágico, embolia pulmonar, insuficiência renal aguda, e septicemia e três casos por causas indeterminadas. Os principais fatores de risco foram: idade > 25 anos, multiparidade, idade gestacional < 32 semanas, falta de pré-natal, pressão diastólica > $110 \mathrm{mmHg}$, convulsões, hipertensão arterial sistêmica crônica, síndrome HELLP, edema agudo de pulmão, descolamento prematuro de placenta, coagulopatia intravascular disseminada e insuficiência renal aguda. As variáveis que persistiram associadas com morte materna foram: síndrome HELLP, eclâm-psia, edema agudo de pulmão, hipertensão crônica e falta de pré-natal.

Conclusões: os principais fatores de risco para morte em mulheres com pré-eclâmpsia/eclâmpsia são falta de pré-natal associados com hipertensão crônica e complicações como síndrome HELLP, eclâmpsia e edema agudo de pulmão.

Palavras-chave Eclâmpsia, Hipertensão, Morte, Fatores de risco 


\section{Introduction}

Arterial hypertension is still the most prevailing maternal death cause. It is estimated that, throughout the world, 50.000 women die annually of eclampsia. ${ }^{1}$ In Brazil, hypertension syndromes represent the first cause of maternal mortality comprising $35 \%$ of all cases. ${ }^{2}$ In Recife, $23,8 \%$ of maternal deaths were caused by hypertension.

Even in developed countries, such as the United States, approximately $18 \%$ of the maternal death toll is caused by pregnancy induced hypertension complications.4,5. These are represented by acute pulmonary edema, eclampsia, acute renal failure, the HELLP syndrome, abruptio placenta, disseminated intravascular coagulation and pulmonary embolism.6-11 These, associated to preeclampsia, aggravates maternal prognosis demanding clinical and obstetrical emergency treatment.

Notwithstanding the fact that several studies have been conducted aiming at the identification of maternal death related risks factors, ${ }^{10,14}$ studies strictly focusing patients with preeclampsia/eclampsia $^{8}$ are rare. Considering the still existing impossibility of preeclampsia prevention (the majority of clinical essays failed in demonstrating the efficacy of different therapies such as aspirin, calcium and other modalities), we felt it was important to identify, among patients with severe preeclampsia/eclampsia, the ones carrying the greater risk for maternal death.

This study was performed with the objective of determining the principal death causes in patients with severe preeclampsia/eclampsia and identifying related risk factors.

\section{Methods}

An analytical study, of the case-control type was performed. The files of 2.541 patients with severe preeclampsia/eclampsia who had their deliveries assisted in the Centro de Atenção à Mulher do Instituto Maternal Infantil de Pernambuco (CAM/IMIP) between 1992 and 1997 were studied. There were 20 maternal deaths in the period $(0,79 \%)$ comprising the cases whose basic causes were studied. Considering the already detected 20 cases, the calculations of the sample size of the Statcalc program of Epi-Info $6.04 \mathrm{~b}$, alpha error of $5 \%$ and an $80 \%$ admitted power, were performed. As the frequency of abruptio placenta was known, consisting of $30 \%$ of death causes and around $4 \%$ among all of the preeclampsia cases in the hospital, 80 controls would then be re- quired (in the proportion of four controls for each case) to depict this difference. These 80 controls were randomly selected among the remaining files based on a randomized numeric table.

Whether maternal death occurred or not was determined to be the dependent variable. Independent variables considered were: age, parity, time of pregnancy, arterial pressure rates in admission (systolic and diastolic arterial pressure), lack or presence of prenatal care, previous admission in the high-risk ward of the CAM-IMIP, lack or presence of convulsions (eclampsia) and the HELLP syndrome, association with preexistent chronic hypertension (superimposed preeclampsia), delivery procedure (transpelvic or cesarean section) and associated complications (acute pulmonary edema, acute renal failure, abruptio placenta, coagulation disorders, sepsis, pulmonary embolism).

\section{Terms and variables definition}

Preeclampsia diagnosis was made in the presence of arterial hypertension (systolic pressure of $\geq 140$ and/or diastolic pressure $\geq 90 \mathrm{mmHg}$, proteinuria (1 + by labstix in 2 occasions or $2+$ or more in isolated dosage or yet $\geq 300 \mathrm{mg} / 1 / 24$ hours) and hyperuricemia (uric acid $\geq 4,5 \mathrm{mg} \%$ ) edema related or not. 15 Severe preeclampsia diagnosis was defined in the presence of any one of the signs and symptoms in patients with preeclampsia: arterial pressure of $\geq$ $160 / 110 \mathrm{mmHg}$, proteinuria $\geq 2 \mathrm{~g} / \mathrm{L} / 24$ hours or labstix of $3+$ or more, oliguria/oligoanuria $(\downarrow 25 \mathrm{ml}$ of urine/hour), serum creatinine $>1,2 \mathrm{mg} \%$, signs and symptoms of iminent eclampsia, characteristic findings of the HELLP syndrome, cyanosis or lung acute edema, funduscopic findings of hemorrhages, retinian exudates and papyloedema. 15 Eclampsia has been diagnosed as the occurrence of tonic-clonic generalized convulsion in patients with pre-eclampsia diagnosis. Superimposed preeclampsia was considered in the presence of these parameters in addition to chronic arterial systemic hypertension (SAH). 15 The HELLP syndrome was defined as indicated by platelets below $100.000 / \mathrm{mm}^{3}$, transaminase above 70U/L lactic desidrogenase (DHL) above $600 \mathrm{mg} \%$ and bilirubin $>1,2 \mathrm{mg} \% 16$ whether or not associated to clinical manifestations such as anemia, jaundice, epigastralgia and coagulapathy. Tracking of laboratory parameters was systematically accomplished in all patients with preeclampsia/eclampsia diagnosis independently of the adopted management (active or temporizing) or disease severity. 17 Prenatal care was considered as the accomplishment of at least five medical visits before delivery. 
Associated complications considered were, acute pulmonary edema and the presence of tachydyspnea, cyanosis, tachycardia and crepitant stertors. ${ }^{4}$ Acute renal failure was diagnosed in the presence of olygoanuria ( $<400 \mathrm{ml} / 24$ hours) related to high urea and creatinin levels. 22 Disseminated intravascular coagulation (DIC) was defined in the presence of hemorrahagic manifestations (ecchymosis, petechiae, gum bleeding, genital bleeding, bleeding from puncture or surgical wound sites) and alteration of clotting tests. 18 One or more episodes of hematemesis indicating digestive hemorrhage. Cerebral hemorrhage was diagnosed by computerized tomography and/or magnetic resonance in patients with clinical findings. Hemorrhagic shock was defined by the criteria proposed in ATLS18 and sepsis as the inflammatory systemic response syndrome according to Bone's 19 criteria. Pulmonary embolism diagnosis was determined by necropsy in one patient and assumed by characteristic radiological and clinical findings (abrupt dyspnea, hemoptysis and syncope followed by cardiorespiratory arrest within minutes) 17 in another patient whose family did not allow the performance of necropsy.

\section{Patients' follow-up procedures and pregnancy interruption}

In severe preeclampsia with less than 34 weeks, management was temporizing in the absence of maternal complications and any of the HELLP syndrome parameters, provided fetal vitality was satisfactory. 17,20 Pulmonary fetal maturity was determined by Clements test in severe preeclampsia from the $30^{\text {th }}$ week on. Intervention in the $34^{\text {th }}$ week was adopted in the presence of fetal pulmonary maturity, as well as in the occurrence of any maternal complications. In favorable cervical conditions and good fetal vitality, delivery was induced. If these were not present, cesarean section was indicated. All patients with eclampsia had their pregnancies interrupted following stabilization of maternal conditions and delivery procedure was indicated related to severe preeclampsia indications. Magnesium sulfate related to the Zuspan scheme was administered for prophylaxis (in cases of severe preeclampsia) or control of eclamptic convulsions. 17 The diagnosis of the HELLP syndrome was an indication of systematic pregnancy interruption as soon as the mother's condition allowed.

\section{Statistical analysis}

Accomplished with statistical programs Epi-Info 6.04b (freeware) and Statistical Package for Social Sciences (SPSS) 6.0 version for Windows. Averages and respective standard deviations were calculated for quantitative variables (age, parity, and pregnancy time) through the Mann-Whitney test for two group's difference at a significance level of 5\%. In the bivariable analysis the odds ratio (and confidence interval at $95 \%, 95 \% \mathrm{CI}$ ) as a relative risk estimate of maternal death (dependent variable) for different risk factors related to maternal death (variable dependent) for different risk factors (independent variables). Following, a multiple logistic regression analysis was performed using two models, the first in which all variables were included, coded as yes = $1 /$ no $=0$ (related to presence or absence) and the second in which maternal death inducing complications were excluded. Subsequently this model was built with the objective of determining the variables which best-explained maternal death, without considering the complications, which, in their majority, represented the direct cause of death. The utilized command was "Backward: conditional", with stepwise analysis in which the variables that do not contribute significantly $(p>0,05)$ are eliminated at each one of the steps. The adjusted odds ratio and its respective $95 \%$ CI were calculated.

\section{Results}

Acute pulmonary edema is the principal cause of maternal death in patients with preeclampsia/ eclampsia in the IMIP (30\%) followed by DIC $(25 \%)$, hemorrhagic shock $(10 \%)$, pulmonary embolism (10\%). Acute renal failure and sepsis represented respectively $5 \%$ of death causes. Cause of death remained undetermined in $15 \%$ of the patients (Table 1). 


\section{Table 1}

Death causes in patients with preeclampsia/eclampsia. Instituto Materno Infantil de Pernambuco (IMIP), 1992 a 1997.

\begin{tabular}{lcc}
\hline Death cause & $\mathbf{n}^{\circ}$ & $\%$ \\
\hline Acute pulmonary edema & 6 & 30,0 \\
Disseminated intravascular coagulation & 5 & 25,0 \\
Hemorrhagic shock & 2 & 10,0 \\
Pulmonary embolism & 2 & 10,0 \\
Acute renal failure & 1 & 5,0 \\
Sepsis & 1 & 5,0 \\
Total & 20 & 100,0 \\
\hline
\end{tabular}

The comparison of maternal death cases and the controls (Table 2) indicated a significantly increased age average between cases (30,6 years old versus 23,7 years old of the control group). Parity was significantly different with an median of one for the cases and 0 for the controls. There was a significant difference in the pregnancy age average, which was of 34,4 weeks for the cases and 37,2 for the controls. There was no difference between systolic blood pressure, but the levels of diastolic blood pressure were higher among the cases (mean of $119 \mathrm{mmHg}$ ) than among the controls (mean $113 \mathrm{mmHg}$ ) ( $\mathrm{p}<$ $0,05)$.

\section{Table 2}

Comparison of age, parity, time of pregnancy and blood pressure levels among the cases of maternal death by preeclampsia/eclampsia and the controls. Instituto Materno Infantil de Pernambuco (IMIP), 1992 a 1997.

\begin{tabular}{lrrrc}
\hline \multirow{2}{*}{ Variable } & Cases $(\mathbf{n}=\mathbf{2 0})$ & Controls $(\mathbf{n}=\mathbf{8 0})$ & $\mathbf{P}$ \\
\cline { 2 - 5 } & $\bar{X} \pm \mathrm{dp}$ & $\overline{\mathrm{X}} \pm \mathrm{dp}$ & \\
\hline Age & $30,6 \pm 5,3$ & $23,7 \pm 6,1$ & $<0,0001$ \\
Parity & $1,8 \pm 1,4$ & $0,3 \pm 0,6$ & 0,04 \\
Pregnancy age & $34,4 \pm 3,4$ & $37,2 \pm 3,6$ & 0,002 \\
Systolic arterial ressure (PAS) in admission & $179,9 \pm 28,4$ & $166,8 \pm 17,1$ & $\mathrm{NS}$ \\
Diastolic arterial pressure (PAD) in admission & $119,9 \pm 12,6$ & $113,4 \pm 9,2$ & 0,01 \\
& & & & \\
\hline
\end{tabular}

SD = standard deviation; NS = no significant.

Analysis of the association between age and maternal death, established that the cases with significantly more chances $(3,89$ times) were the ones of patients over 25 years old, and even further chances
(5,67 times) for patients over 30 years old (Table 3 ). When parity was considered, the chance of multiparity was significantly higher (4,2 times) for the cases of maternal death (Table 4)

\section{Table 3}

Maternal death relative risk in patients with preeclampsia/eclampsia according to age group. Instituto Materno Infantil de Pernambuco (IMIP), 1992 a 1997.

\begin{tabular}{ccccc}
\hline Age (years) & Cases $(\mathrm{n}=\mathbf{2 0})$ & Controls $(\mathrm{n}=\mathbf{8 0})$ & Odds ratio & $\mathbf{9 5 \% C l}$ \\
\hline$>25$ & 14 & 30 & 3,89 & $1,22-13,5$ \\
$\leq 25$ & 6 & 50 & 1,00 & \\
\hline$>30$ & 10 & 12 & 5,67 & $1,72-19,72$ \\
$\leq 30$ & 10 & 68 & 1,00 & \\
\hline
\end{tabular}


Maternal death relative risk in patients with preeclampsia/eclampsia according to parity. Instituto Materno Infantil de Pernambuco (IMIP), 1992 a 1997.

\begin{tabular}{|c|c|c|c|c|}
\hline Parity & Cases $(n=20)$ & Controls $(n=80)$ & Odds ratio & $95 \% \mathrm{Cl}$ \\
\hline Multiparous & 12 & 21 & 4,21 & $1,36-13,32$ \\
\hline Primiparous & 8 & 59 & 1,00 & \\
\hline
\end{tabular}

For pregnancy time analysis two cutoff points were considered: under 32 weeks and under 37 weeks, with a significantly increased risk of respectively 4,85 times and 3,2 times, for the cases (Table 5). Considering prenatal care, the chance of inadequate or lacking prenatal care was around four times more for the cases, and this risk was significant (Table 6). Although the chance of admission in the high risk ward of IMIP was lower for the cases (OR $=0,29$ ), this difference was not statistically significant (interval confidence limits included the unit) (Table 7).

Table 5

Maternal death relative risk in patients with preeclampsia/eclampsia according to pregnancy age. Instituto Materno Infantil de Pernambuco (IMIP), 1992 a 1997

\begin{tabular}{ccccc}
\hline Pregnancy age (weeks) & Cases $(\mathbf{n}=\mathbf{2 0})$ & Controls $(\mathbf{n}=\mathbf{8 0})$ & Odds ratio & $95 \% \mathrm{Cl}$ \\
\hline$<32$ & 7 & 8 & 4,85 & $1,30-18,32$ \\
$\geq 32$ & 13 & 72 & 1,00 & $1,06-9,96$ \\
$<37$ & 11 & 22 & 3,22 & 1,00 \\
\hline 37 & 9 & 58 & \\
\hline
\end{tabular}

\section{Table 6}

Maternal death relative risk in patients with preeclampsia/eclampsia according to the presence or absence of prenatal care. Instituto Materno Infantil de Pernambuco (IMIP), 1992 a 1997.

\begin{tabular}{|c|c|c|c|c|}
\hline Prenatal care & Cases $(n=20)$ & Controls $(n=80)$ & Odds ratio & $95 \% \mathrm{Cl}$ \\
\hline $\begin{array}{l}\text { Not performed or less than five } \\
\text { medical visits }\end{array}$ & 15 & 34 & 4,06 & $1,22-14,3$ \\
\hline Five or more medical visits & 5 & 46 & 1,00 & \\
\hline
\end{tabular}


Relative maternal death risk in patients with preeclampsia/eclampsia according to whether or not there was admission in the high risk ward. Instituto Materno Infantil de Pernambuco (IMIP), 1992 a 1997.

\begin{tabular}{ccccc}
\hline Admission in high risk ward & Cases $(\mathbf{n}=\mathbf{2 0})$ & Controls $(\mathbf{n}=\mathbf{8 0})$ & Odds ratio & $95 \% \mathrm{Cl}$ \\
\hline Yes & 2 & 22 & 0,29 & $0,04-1,49$ \\
No & 18 & 58 & 1,00 &
\end{tabular}

Systolic arterial pressure levels were not significantly related to maternal death, although the chances of patients dying because of systolic arterial pressure above $160 \mathrm{mmgHg}$ were $40 \%$ higher. On the other hand, the cases of maternal death had a 3,86 times higher chance of presenting diastolic blood pressure above $110 \mathrm{mmHg}$ (Table 8 ).
Patients lost to maternal death had a significantly increased chance of presenting the following situations: eclampsia $(\mathrm{OR}=11,0)$, HELPP syndrome $(\mathrm{OR}=15,5)$ and superimposed preeclampsia $(\mathrm{OR}=$ 6,5) (Tables 9, 10 and 11). There were no significant differences in relation to the delivery procedure (Table 12).

Table 8

Maternal death relative risk in patients with preeclampsia/eclampsia according to pressure levels in admission. Instituto Materno Infantil de Pernambuco (IMIP), 1992 a 1997.

\begin{tabular}{|c|c|c|c|c|}
\hline Pressure levels during admission. & Cases $(n=20)$ & Controls $(n=80)$ & Odds ratio & $95 \% \mathrm{Cl}$ \\
\hline \multicolumn{5}{|l|}{ Systolic pressure } \\
\hline$>160 \mathrm{mmHg}$ & 14 & 50 & 1,4 & $0,44-4,62$ \\
\hline$\leq 160 \mathrm{mmHg}$ & 6 & 30 & 1,00 & \\
\hline \multicolumn{5}{|l|}{ Diastolic pressure } \\
\hline$>110 \mathrm{mmHg}$ & 9 & 14 & 3,86 & $1,19-12,58$ \\
\hline$\leq 110 \mathrm{mmHg}$ & 11 & 66 & 1,00 & \\
\hline
\end{tabular}

Table 9

Relative risk of maternal death in patients with preeclampsia/eclampsia according to the presence or absence of convulsions. Instituto Materno Infantil de Pernambuco (IMIP), 1992 a 1997.

\begin{tabular}{|c|c|c|c|c|}
\hline Eclampsia & Cases $(n=20)$ & Controls $(n=80)$ & Odds ratio & $95 \% \mathrm{Cl}$ \\
\hline Yes & 6 & 3 & 11,00 & $2,08-64,46$ \\
\hline No & 14 & 77 & 1,00 & \\
\hline
\end{tabular}


Maternal death relative risk in patients with preeclampsia/eclampsia according to the presence of absence of the HELLP syndrome. Instituto Materno Infantil de Pernambuco (IMIP), 1992 a 1997.

\begin{tabular}{ccccc}
\hline HELLP syndrome & Cases $(\mathbf{n = 2 0 )}$ & Controls $(\mathbf{n = 8 0})$ & Odds ratio & $95 \% \mathrm{Cl}$ \\
\hline Yes & 9 & 4 & 15,5 & $3,52-74,36$ \\
No & 11 & 76 & 1,00 &
\end{tabular}

\section{Table 11}

Maternal death relative risk in patients with preeclampsia/eclampsia according to the presence of absence of chronic hypertension (superimposed preeclampsia). Instituto Materno Infantil de Pernambuco (IMIP), 1992 a 1997.

\begin{tabular}{lcccc}
\hline Chronic hypertension & Cases $(\mathrm{n}=\mathbf{2 0})$ & Controls $(\mathrm{n}=\mathbf{8 0})$ & Odds ratio & $\mathbf{9 5 \% C l}$ \\
\hline Present & 12 & 15 & 6,5 & $2,02-21,5$ \\
Absent & 8 & 65 & 1,00 & \\
\hline
\end{tabular}

\section{Table 12}

Maternal death relative risk in patients with preeclampsia/eclampsia according to delivery procedure. Instituto Materno Infantil de Pernambuco (IMIP), 1992 a 1997.

\begin{tabular}{lcccc}
\hline Procedures of delivery & Cases $(\mathbf{n}=\mathbf{2 0})$ & Controls $(\mathbf{n}=\mathbf{8 0})$ & Odds ratio & $\mathbf{9 5 \%} \mathrm{Cl}$ \\
\hline Transpelvic & 16 & 48 & 2,67 & $0,74-10,46$ \\
Cesarean section & 4 & 32 & 1,00 & \\
\hline
\end{tabular}

In the presence of related complications, the chance of maternal death in the presence of the following complications was significantly higher in relation to the controls (Table 13): acute pulmonary edema $(\mathrm{OR}=16,7)$, normally inserted abruptio placenta, NIAP $(\mathrm{OR}=11,0)$, disseminated intravascular coagulation $(\mathrm{OR}=26,3)$ and acute renal failure $(\mathrm{OR}$ $=19,75)$. 
Maternal death risk in the presence or absence of related complications. Instituto Materno Infantil de Pernambuco (IMIP), 1992 a 1997.

\begin{tabular}{lcccc}
\hline Complications & Cases $(\mathbf{n}=\mathbf{2 0})$ & Controls $(\mathbf{n = 8 0})$ & Odds ratio & $\mathbf{9 5 \%} \mathbf{C l}$ \\
\hline Acute pulmonary edema & 6 & 2 & 16,7 & $2,62-135,24$ \\
Normally inserted abruptio placenta & 6 & 3 & 11,0 & $2,08-64,46$ \\
Disseminated intravascular coagulation & 5 & 1 & 26,33 & $2,63-641,07$ \\
Acute renal failure & 4 & 1 & 19,75 & $1,85-497,22$ \\
Hemorrhagic shock & 2 & - & - & - \\
Pulmonary embolism & 2 & - & - & - \\
Sepsis & 1 & - & -
\end{tabular}

Multiple logistic regression analysis indicated that the factors strongly related to maternal death in model one (Table 14) including complications, were the following: HELPP syndrome $(\mathrm{OR}=9,2)$, superimposed preeclampsia $(\mathrm{OR}=5,4)$, acute pulmonary edema $(\mathrm{OR}=10,4)$ and normally inserted abruptio placenta $(\mathrm{OR}=6,4)$. In model two $($ Table 15$)$ in which maternal complications were not included, an association between maternal death and the following variables: the HELLP syndrome $(\mathrm{OR}=8,4)$, eclampsia $(\mathrm{OR}=6,0)$, superimposed preeclampsia $(\mathrm{OR}=4,5)$ and lack of prenatal care $(\mathrm{OR}=3,6)$ was evidenced.

\section{Table 14}

Adjusted maternal death relative risk - multiple logistic regression (Model 1). Instituto Materno Infantil de Pernambuco (IMIP), 1992 a 1997.

\begin{tabular}{lcc}
\hline Risk Factors & Adjusted Odds ratio & $\mathbf{9 5 \%} \mathbf{C l}$ \\
\hline HELLP syndrome & 9,2 & $2,89-16,23$ \\
Superimposed preeclampsia & 5,4 & $1,92-10,45$ \\
Acute pulmonary edema & 10,4 & $2,42-83,54$ \\
Abruptio placenta & 6,4 & $1,8-32,26$ \\
\hline
\end{tabular}

Table 15

Adjusted maternal death relative risk - multiple logistic regression (Model two). Instituto Materno Infantil de Pernambuco (IMIP), 1992 a 1997.

\begin{tabular}{lcc}
\hline Risk Factors & Adjusted Odds ratio & 95\% Cl \\
\hline HELLP syndrome & 8,4 & $2,54-15,16$ \\
Eclampsia & 6,0 & $1,9-18,57$ \\
Superimposed preeclampsia & 4,5 & $1,85-12,60$ \\
Lack of prenatal care & 3,6 & $1,58-9,40$ \\
\hline
\end{tabular}




\section{Discussion}

The risk factors with significant relation to maternal death in this study were: age over 30 years old, multiparity, pregnancy's time at the moment of pregnancy interruption under 32 weeks, diastolic blood pressure levels over $110 \mathrm{mmHg}$ in admission, chronic arterial pre-existing hypertension (superimposed eclampsia), absence of prenatal care and presence of complications such as eclampsia, the HELLP syndrome, acute pulmonary edema, coagulopathy and acute renal failure.

Several studies point towards older age as a risk factor for maternal death.5,14,21 This increased risk is related to the greater prevalence of chronic diseases in general beginning at 35 years of age. In this study the association to chronic arterial hypertension, which characterizes superimposed preeclampsia occurred in $60 \%$ of the cases of maternal death and remained as one of the strongest death related variables, even after potentially confusing factors were controlled through multiple logistic regression. It should be emphasized that in addition to that, the older age group and its important frequency of chronic hypertension, a large number of maternal death cases were consistently the ones of multiparous women, reflecting the public health system failure especially concerning birth control. It should be noted that although preeclampsia is more frequent in young and primiparous women, the outcome is worse when occurring in older and multiparous women. Sibai et al17,22 refer to an increased risk of the HELLP syndrome in these women and increase mortality of this group and that is corroborated by several other authors. To avoid these deaths, Faundes et al. 23 proposed interventions not only in terms of diagnosis and treatment of the diseases that increase maternal risk but pregnancy prevention as well for the high-risk group of maternal death, though contraceptives.

The lack of prenatal care showed a strong association to maternal death. In reality, $75 \%$ of the cases of maternal death were devoid of prenatal care or with less than five medical visits. This information is very consistent with the already cited pregnancy problems in women over 30 years old, multiparous, with chronic hypertension, who get pregnant away from the public health system and keep away from it. Unfavorable social and economic conditions, the distance from healthcare clinics, the need to mind for the other children in the family hinders the access of these pregnant women to prenatal care causing the progression to severe diseases, and admission only when complications become out of control, with fre- quent abruptio placenta and acute pulmonary edema.7,10 In our study, the majority of pregnant women were admitted in desperate health conditions, pregnancy was interrupted within a short period of time and only two of them had been previously admitted to the high risk pregnancy ward for temporizing management. Several other studies corroborate this finding, demonstrating the association between insufficient or non-existent prenatal care and maternal death7,14,21 pointing towards the need for strategies to increase prenatal care coverage at primary, secondary and tertiary levels. 21,23

As for the complications directly related to death, the risk indicated by our study is similar to what is described in practically all literature related to hypertension syndromes in pregnancy.6,7,10,13,22,26 Acute pulmonary edema is one of the severest clinical emergencies complicating obstetric patients 7 related to an expressive increase of maternal and perinatal morbidity and mortality and significantly more frequent in chronic hypertension and superimposed preeclampsia. In a previous study, we have demonstrated a mortality rate of $18,5 \%$ in the presence of acute pulmonary edema. 7 The HELLP syndrome, on the other hand, significantly compounds the evolution of severe preeclampsia aggravating maternal and perinatal outcomes. $11,12,22,24$ Maternal mortality in the HELLP syndrome is very high, rates between one and $30 \%$ have been described.6,8,10,12,22,24 In our evaluation of 35 cases with the HELLP syndrome mortality rate, around $11 \%$ was determined. It is important to further emphasize that these complications are generally related to acute pulmonary edema, to the HELPP syndrome, acute renal failure, disseminated intravascular coagulation and other6,13,22,24,26 which very much aggravates maternal prognosis.

It is our belief that risk identification and risk quantification for maternal death in all of the described circumstances are of fundamental value in treating patients with severe preeclampsia, particularly when a decision must be made in favor of a temporizing approach in the early stages of pregnancy for it permits the identification of an increased risk sub-group for maternal death, in which complications are frequent. Although a temporizing approach is not counter-indicated in these cases, 27 all care for maternal surveillance should be employed aiming at an early identification of complications giving rise to a greater mortality risk. 9,20 A temporizing approach is generally adopted in the early stages of pregnancy aiming at improving perinatal outcome postponing the interruption of pregnancy to further improve the fetus weight and to reduce the incidence of the hyaline membrane disease.17,20 
Nevertheless it is precisely in the early stages of pregnancy that severe events tend to take place, with the poorest maternal prognosis under 32 weeks of pregnancy.6,8,10 Rigorous maternal surveillance is thus mandatory and ideally, pregnancy should be interrupted before severe complications set in. The continuation of a temporizing approach is not recommended in the occurrence of the HELLP syndrome, acute pulmonary edema and eclampsia. 17,20

Notwithstanding these considerations, we should emphasize that tertiary level care will be only resolving a minimal part of the problem, because as al- ready stated, a temporizing approach will not be possible in the presence of very severe cases, admitted into the hospital in very unfavorable clinical conditions, with catastrophic complications. Although it is not possible to underestimate the value of tertiary care, effective strategies to reduce maternal mortality must encompass primary and secondary care, not only in terms of adequate prenatal care as well as pre-conceptual identification of women at a high risk pregnancy condition to whom efficient contraceptive measures should be offered.

\section{References}

1. Duley L. Maternal mortality related with hypertensive disorders of pregnancy in Africa, Asia, Latin America and the Caribbean. Br J Obstet Gynecol 1992; 99: 547-52.

2. Ministério da Saúde. Mãe, uma vida que vale por duas. Brasília, DF: United Nations Population Fund, Ministério da Saúde, 1993.

3. Cecatti JG, Albuquerque RM, Hardy E, Faúndes A. Mortalidade materna em Recife: causas de óbitos maternos. RBGO: Rev Bras Ginecol Obstet 1998; 20: 7-11.

6. Berg CJ, Atrash HK, Koonin LM, Tucker M. Pregnancy-related mortality in the United States, 1987-1990. Obstet Gynecol 1996; 88: 161-6.

5. Koonin LM, MacKay AP, Berg CJ, Atrash HK, Smith JC. Pregnancy-related mortality surveillance-United States, 1987-1990. Mor Mortal Wkly Rep CDC Surveill Summ 1997; 46: 17-36.

6. Abroug F, Boujadria R, Nouira S, Abroug S, Souissi M, Najjar MF, Secourgeon JF, Bouchoucha S. Hellp syndrome: incidence and maternal-fetal outcome - a prospective study. Intensive Care Med 1992; 18: 274-7.

7. Amorim MMR, Santos LC, Porto AM, Martins LKD. Edema agudo de pulmão nas formas graves da DHEG. Ginecol Obstet Atual 1998; 7: 8-16.

8. Bouaggad A, Laraki M, Bouderka MA, Harti A, el-Mouknia M, Barrou H, Benaguida M. Les facteurs du progrnostic maternel dans l'eclampsie grave. Rev Fr Gynecol Obstet 1995; 90: 205-7.

9. Cunningham FG, Mac Donald PC, Gant NF, Leveno K, Gary DV Gilstrap H, Clark SL. Hypertensive disorders in pregnancy. In: Williams Obstetrics. 20th ed. Norwalk: Appleton e Lange; 1997. p. 693-744.

10. Santos LC, Amorim MMR, Porto AMF, Cardoso MP. HELLP síndrome: estudo de 35 casos. Ginecol Obstet Atual 1997; 6: 20-9.

11. Onrust S, Santerna JG, Aarnoudse JG. Pre-eclampsia and the HELLP syndrome still cause maternal mortality in the Netherlands and other developed countries; can we reduce it? Eur J Obstet Gynecol Reprod Biol 1999; J82: 41-46

12. Sibai BM, Ramadam MK, Usta I, Salama M, Mercer BM, Friedman SA. Maternal morbidity and mortality in 442 pregnancies with hemolysis, elevated liver enzymes and

low platelets (HELLP Syndrome). Am J Obstet Gynecol 1993; 169: 1000-6.

13. Sibai BM, Villar MA, Mabie BC. Acute renal failure in hypertensive disorders of pregnancy. Pregnancy outcome and remote prognosis in thirty-one consecutive cases. Am J Obstet Gynecol 1999; 162: 777-83.

14. Albuquerque RM, Cecatti JG, Hardy E, Faúndes A. Fatores sócio-demográficos e de assistência médica associados ao óbito materno. RBGO: Rev Bras Ginecol Obstet 1998; 20: 181-5.

15. National High Blood Pressure Working Group. Report on high blood pressure in pregnancy (Consensus report). Am J Obstet Gynecol 1990; 163: 1689-712.

16. Weinstein L. Preeclampsia/eclampsia with hemolysis, elevated liver enzymes and thrombocitopenia. Obstet Gynaecol 1985; 66: 657-61.

17. Santos LC, Carvalho MMRA, Porto AM, Guimarães VG. Obstetrícia: diagnóstico e tratamento. Rio de Janeiro: Medsi; 1997. p. 355-73.

18. Alexander RH, Proctor HJ, editors. Advanced trauma and life support. Chicago: American College of Surgeons; 1993.

19. Bone RC, Balk RA, Cerra FB, Dellinger RP, Fein AM, Knaus WA, Schein RM, Sibbald WJ. Definitions for sepsis and organ failure and guidelines for the use of innovative therapies in sepsis. Chest 1992; 101: 1644-55.

20. Santos LC, Carvalho MMRA, Porto AM. Como eu trato: DHEG grave. Ginecol Obstet Atual 1997; 8: 12-7.

21. Chaves Netto H, Fonseca AL, Amim Júnior J. Prevençäo da morte materna na gestaçäo de alto risco In: Faúndes A, Cecatti JG. Morte materna: uma tragédia evitável. Campinas: Universidade Estadual de Campinas; 1991. p. 99-118.

22. Sibai BM, Taslimi MM, El-Nazer A, Amon E, Mabie BC, Ryan GM. Maternal-perinatal outcome related with the syndrome of hemolysis, elevated liver enzymes and low platelets in severe preeclampsia/eclampsia. Am J Obstet Gynecol 1986; 155: 501-9.

23. Faúndes A, Cecatti JG, Bacha AM, Pinotti JA. Intervençöes para a reduçäo da mortalidade materna. Rev Paul Med 1989; 107: 47-52.

24. Sibai BM. The HELLP syndrome (Hemolysis, Elevated li- 
ver enzymes and low platelets): much ado about nothing? Am J Obstet Gynecol 1990; 162: 311-6.

25. Zugaib M, Barros ACSD, Bittar RE, Kahhale S, Schultz R, Neme B. A mortalidade materna na eclâmpsia. J Bras Ginecol 1985; 95: 129-36.

26. Sibai BM. Eclampsia. VI. Maternal-perinatal outcome in 254 consecutive cases. Am J Obstet Gynecol 1990; 163: 1049-54.

27. Visser W, Wallenburg HC. Maternal and perinatal outcome of temporizing management in 254 consecutive patients with severe pre-eclampsia remote from term. Eur J Obstet Gynecol Reprod Biol 1995; J82: 147-54 